Volume 2 Issue 1, January-June 2021: pp. 37-48 Indonesian Private Law Review.

Fakultas Hukum, Universitas Lampung, Bandar Lampung, Indonesia.

\title{
LEGAL PROTECTION OF DISADVANTAGED DEBTOR CUSTOMERS IN THE IMPLEMENTATION OF OBJECT EXECUTION AUCTION PROCEDURES IN BANK CREDIT AGREEMENTS
}

\author{
Disa Soraya \\ Universitas Malahayati \\ disabahajad21@gmail.com
}

Submitted: January 19, 2021; Reviewed: January 26, 2020; Accepted: February 17, 2021

DOI: 10.25041/iplr.v2i1.2224

\begin{abstract}
In the process of granting credit, it often happens that the creditor loses when the debtor defaults so that legal rules are required in the implementation of the imposition of the mortgage as stated in a credit agreement, which aims to provide legal certainty and protection for the parties concerned. So, it raises a lawsuit for the cancellation of the auction. Based on these problems, this research aims to answer problems regarding the auction implementation of mortgage rights against debtors who are negligent by the Bank, limits on the determination of the auction limit value for the object of guarantee rights of security rights, and legal protection for bank customers for auction that does not match the value of a collateral object. This study uses an empirical juridical method by conducting literature studies and interviews with informants. The research and discussion results found that: First, the implementation of the mortgage right execution auction can be used as an alternative when bad credit occurs as a result of the customer (the debtor) in default to his creditor. The Bank, as the creditor, has the right to collect receivables from the sale of the object of the mortgage, which is guaranteed by an auction mechanism following the provisions of Law Number 4 of 1996 concerning Mortgage Rights for Land and Other Objects Related to Land. Mortgage rights in the credit agreement have a function to provide a sense of security for creditors in case of default by the debtor through the mortgage's execution. Second, the limit value's determination must be determined based on an appraiser's assessment. So that if the determination of the limit value is so low, it can be used as one of the reasons for the auction's cancellation. This is based on the provisions of Article 43 and Article 44 of the Regulation of the Minister of Finance of the Republic of Indonesia Number 27/PMK.06/2016 concerning Instructions for Conducting Auctions. Third, as a guarantee of legal protection for customers, if there is a loss due to implementing an auction that is not based on applicable legislation.
\end{abstract}

Keywords: Legal Protection, Execution Auction, and Mortgage Rights

\section{A. Introduction}

An increase in the economy rate will lead to the growth and development of business carried out by the community. Usually, business actors in developing their business always try to increase their business capital by making loans or direct credit or direct credit to banks. In conducting its business, Indonesian banking is based on economic democracy using 
precautionary principles. ${ }^{1}$ Included in providing credit as one of its business fields, banks must prioritize the precautionary principle. In providing credit, banks can ask for guarantees to their customers (debtors) as an indicator of implementing the precautionary principle. ${ }^{2}$ This is necessary to maintain a balance of protection for both parties, both the Bank as the creditor and the customer as the debtor who receives credit. The provision of credit given by the Bank as a financial institution must provide legal protection for both parties, namely the credit provider as the creditor and the credit recipient as the debtor. Of course, the legal protection provided is obtained through a vital guarantee rights institution that can provide legal certainty for interested parties.

Mortgage rights are one of the guarantees that are commonly practised in providing credit for various purposes. This is possible considering that most people are considered the most appropriate to be used as a guarantee by paying attention to various factors, including the safety factor and the certainty factor. So, in this regard, there are provisions that stipulate that the following guarantees or not, along with other objects on the land, are used as collateral, which is an inseparable unit. This is regulated in Law Number 4 of 1996 concerning Mortgage Rights for Land and Objects related to land. The mortgage certificate itself has executive power as referred to in law. ${ }^{3}$ Based on this, the mortgage certificate contains the slogan "For Justice Based on the One Godhead". That way, the mortgage certificate has executorial power as if a court decision has permanent legal force. ${ }^{4}$

However, legal protection for those who guarantee their mortgage rights must also be prioritized. This legal protection is intended to create conditions that promote human dignity and enable people to live a fair life according to their dignity. This also means that the creditor's efforts to sell the mortgage object guaranteed to him through an auction mechanism can be carried out legally. So that the auction that is held must be based on stages justified by the provisions of the legislation, then the rights of customers who guarantee their mortgage rights can be protected because they can file legal remedies when there is a legal flaw in the auction process for the execution of the mortgage that is held.

So the rights of customers who guarantee their mortgage rights can be protected because they could file legal remedies when there is a legal flaw in the auction process for the mortgage execution. This has been regulated, namely in Article 6 jo. Article 11 Paragraph (2) of Law Number 4 of 1996 concerning Mortgage Rights regulates the promises contained in the Deed of Granting Mortgage that is held. The promises contained in this Article do not provide legal protection for the creditor. However, only a part of the promise protects the creditor if the debtor defaults. The provisions in Article 11 Paragraph (2) contain the agreement contained in a Deed of Granting Mortgage Rights (APHT), where these promises are a form of legal protection for the right mortgage holder (the creditor), especially if the debtor is in default. This legal protection is in the form of a promise that limits the authority of the guarantor (the debtor) not to take action that is detrimental to the right mortgage holder (the creditor) or a promise that must be made if the debtor defaults, as well as a promise that gives the holder of the security right to do certain things.

\footnotetext{
${ }^{1}$ Lusia Sulastri, "Konstruksi Perlindungan Hukum Debitur Dalam Penyelesaian Kredit Bermasalah Dengan Pelaksanaan Lelang Jaminan Hak Tanggungan," Jurnal Pembaharuan Hukum 2, no. 1 (2016): 86-101, 86, DOI: 10.26532/jph.v2i1.1418.

${ }^{2}$ Nur Laily et al., "Analisis Perlindungan Hukum Terhadap Peserta Lelang Dalam Pelaksanaan Eksekusi Hak Tanggungan Oleh Pihak Bank," Reformasi Hukum 24, no. 2 (2020): 209-228, 209, DOI: 10.46257/jrh.v24i2.140.

${ }^{3}$ Article 14 paragraph (1) of Law Number 4 of 1996 concerning Mortgage Rights for Land and Other Objects Related to Land

${ }^{4}$ Lutfi Walidani and Habib Adjie, "Perlindungan Hukum Kreditur Terhadap Pelaksanaan Eksekusi Hak Tanggungan (Analisis Putusan Mahkamah Agung Republik Indonesia Nomor 2859K/PDT/2011)," Hukum Dan Masyarakat Madani 8, no. 2 (2018): 117-130, 117, DOI: 10.26623/humani.v8i2.1377.
} 
Based on how the object of mortgage is sold through the auction mechanism, which is predicted to have advantages over other methods, it often causes problems. Some of the problems that occur include such as losses suffered by the debtor due to the determination of the limit value, which is far below the fair value of the object as collateral. It is known that the auction mechanism will start from the initial bid according to the limit value determined and announced. If allowed to do so, it can cause excessive losses for debtors whose mortgage object is the collateral to be auctioned off. Therefore, the process of implementing the auction for the execution of the mortgage object at the State Property and Auction Service Office or Pelayanan Kekakyaaan Negara dan Lelang (KPKNL) includes:

1. Preparation of Mortgage Execuiser Auction' Objects

This preparation can be interpreted as a series of activities that must be carried out before auction day and is a part that must be carefully prepared to smooth the auction process and optimize auction results. The auction preparation procedure consists of submitting an auction application, signing the cooperation, receiving documents, checking legal aspects, reviewing assets, and announcing the auction.

2. Implementation of the Auction

After several participants have gathered, the auction can be held. The implementation is led by an auction official whom the auction guide can assist. Participants who have submitted the highest price and have reached the limit value are appointed as auction winners.

3. Activities post the auction.

KPKNL, buyers, and sellers carried out activities after the auction are payment, submission of auction objects, and completion of auction report.

Based on the auction implementation process, in practice determining the limit value below the market price and/or below the liquidation value is sometimes one reason for the cancellation of the auction. ${ }^{5}$ In addition to these reasons, bank customers (debtors) to file an attempt to cancel the auction is that there is an illegal act committed by the Bank as the creditor and/or originating from the auction organizer. In the next section, the authors will describe that parties who object to the implementation of the auction can file a lawsuit for auction cancellation through the local district court. In 2016, there were at least 3,369 cases of auction cancellation lawsuits handled by the Directorate General of State Assets, Ministry of Finance of the Republic of Indonesia. ${ }^{6}$

This research will describe the problems associated with the auction execution of mortgage rights such as: First, the implementation of the auction for the execution of mortgage rights against debtors who are negligent by the Bank, Second, the limit on the determination of the auction limit value on the object of the guaranteed right of guarantee, and Third, legal protection for bank customers for the conduct of auctions that do not match the value of the collateral object.

Based on the problems above, it can be identified that legal problems in the auction sale process are expected. These legal problems can occur both before and after the auction is held. The problems that occur may be due to various factors such as: First, the problems that occur because in some cases, the administration of the State Wealth and Auction Service Office as the auctioneer is related to the implementation of the auction execution of the mortgage right auction is not running well. Second, problems can also occur because of objections or lawsuits relating to the auction for the execution of mortgage rights by parties

\footnotetext{
${ }^{5}$ Supriadi Jufri, Anwar Borahima, and Nurfaidah Said, "Pelaksanaan Lelang Eksekusi Hak Tanggungan Melalui Balai Lelang,” Jurnal Ilmiah Dunia Hukum 4, no. 2 (2020): 95-107, 95, DOI: 10.35973/jidh.v4i2.1379.

6 https://www.djkn.kemenkeu.go.id/kpknl-batam/baca-artikel/12599/Mendorong-Efektivitas-Lelang-EksekusiHak-Tanggungan.html, accessed on May 28, 2020.
} 
whose legal interests have been harmed, including third parties. For the matters mentioned above, it is necessary to conduct a research entitled "Legal Protection of Bank Customers in Execution of Mortgage Execution Auction".

Thus, this research aims to: First, comprehensively analyze the implementation of the auction execution of mortgage rights against debtors who are negligent by the Bank, Second, to analyze the limits for determining the auction limit value for the object of guarantee of mortgage rights comprehensively, and third, to analyze the legal protection of bank customers for the conduct of auctions that do not match the value of the collateral object.

\section{B. Discussion}

\section{Position and Function of Mortgage Rights in Securing Credit Agreements}

The birth of the mortgage right after enacting Law Number 4 of 1996 concerning Mortgage Rights is the only guarantee rights over land in the written national land law. Mortgage rights are a limited type of material right, which only authorizes the right holder to obtain payment of their receivables in advance from the creditor. The mortgage rights law is also the answer to unification in Indonesia's guarantee institutions because this law has been adapted to the institution of mortgage rights. The existence of the mortgage rights law is essential for the legal system, especially the guarantee law, namely in providing certainty in collateral binding for land-related objects as credit collateral.

Efforts to guarantee credit that is carried out are a necessity for the parties involved. ${ }^{7}$ Both the Bank as the creditor and the customer as the debtor. Banks, to ensure that credit is given, are usually not careless and immediately provide loans in the form of credit without any guaranteed rights. ${ }^{8}$ In carrying out its business activities, the Bank continues to base itself on the precautionary principle, ${ }^{9}$ which will always pay attention and continually research the individual's rights. ${ }^{10}$ Likewise, customers as debtors do not want to be outdone in convincing the Bank to disburse credit to them. To increase the Bank's confidence in providing credit, usually, the customer will include a right that will be used as a guarantee for the credit that will be carried out. The debt collateral is in the form of immovable objects, in this case, namely land objects that are already registered or certified. ${ }^{11}$ This is necessary to balance the two so that they have a relatively balanced bargaining position.

In line with this, the Head of Bank Mayora's Credit Operations Division, Shinta Dewi, revealed that checking and analyzing credit was carried out using several assessment indicators: First, the party will assess the nature or character of the prospective customer (the debtor). This is intended so that his party provides credit appropriately to trustworthy people and does not give credit to irresponsible parties. Second, the party will look at the ability of prospective debtors to manage finances. The reference is at least used to detect prospective debtors' ability to pay off loans that will be given. Third, the party will look at the financing sources owned by the prospective debtor, such as monthly income and so on. The reference is

\footnotetext{
${ }^{7}$ M. Ichsan Alfara, "Perlindungan Hukum Bagi Pemenang Lelang Eksekusi Hak Tanggungan Dalam Hal Objek Lelang Yang Tidak Sesuai Dengan Pengumuman Lelang (Studi Kasus Putusan Pengadilan Negeri Manado Nomor 123/PDT.G/2018/PN.MND)," Notary 2, no. 1 (2020): 622-645, 622.

8 Arief Suryono Yelina Rachma Pranamawati, "Perlindungan Hukum Pembeli Lelang Terhadap Pelaksanaan Eksekusi Hak Tanggungan Yang Risalah Lelangnya Dinyatakan Tidak Sah dan Tidak Mempunyai Kekuatan Hukum Mengikat Oleh Pengadilan," Repertorium 5, no. 1 (2018): 220-235, 226.

9 This principle in the banking world is also known as the Prudent Banking Principle (UK), which means wise. Permadi Gandapradja, Dasar dan Prinsip Pengawasan Bank (Jakarta: Gramedia Pustaka Utama, 2004), 21

${ }^{10}$ Rachmadi Usman, Aspek-Aspek Hukum Perbankan di Indonesia (Jakarta: Gramedia Pustaka Utama, 2003), 18

11 Akira Widyanti, "Pelaksanaan Lelang Eksekusi Oleh Kreditur Terhadap Jaminan Sebagai Sarana Pelunasan Hutang Debitur Berdasarkan Pasal 6 Paragraph (1) Undang-Undang Nomor 4 Tahun 1996 Tentang Hak Tanggungan," Rechtsregel : Jurnal Ilmu Hukum 3, no. 1 (2020): 132-146, 137, DOI: 10.32493/RJIH.V3I1.6625.
} 
used to determine the potential success of the prospective debtor in repaying the credit. Fourth, the party will look at the guarantees given by prospective debtors. This guarantee can be physical or non-physical, including mortgage rights. Usually, this guarantee exceeds the amount of credit given to convince him as the creditor to provide credit. And fifth, the party will see the value of the present economic conditions with adjustments to conditions in the future.

Land rights that are the mortgage object as collateral or collateral are commonly practiced in providing credit for various purposes. ${ }^{12}$ For most people, land is considered the most appropriate to be used as collateral for various reasons, one of which is the factor of security and certainty. ${ }^{13}$ Therefore, in this regard, some provisions stipulate that the guarantee or collateral is not only limited to the land but also the following or not along with other objects located on the land which are used as collateral, which is one unit as determined in Law Number 4 of 1996 concerning Mortgage Rights for Land and Other Objects related to land. In its implementation, this condition is explicitly stated in a power of attorney, which imposes the Mortgage Rights and in the Mortgage Deed made by the Land Deed Making Official.

In principle, every execution must be carried out through a public auction. By holding a public auction, it is hoped that the highest price can be obtained for the object of the mortgage, which is used as collateral. ${ }^{14}$ The auction can be used as an alternative for settling bad credit when the customer (the debtor) fails to promise the Bank (the creditor). The Bank, as the creditor, has the right to take the guaranteed receivable settlement from the sale of the object of the mortgage. The rest becomes the mortgage provider's right concerning the sales proceeds, which turn out to be greater than the receivables. Then on the guaranteed mortgage certificate, affixed the letter "For the sake of Justice based on God Almighty" as evidence and has executorial power as a form of legal certainty. With these slogans, the mortgage's executorial power is considered the same as a court decision that has permanent legal force. ${ }^{15}$

In connection with the implementation of the auction for the execution of mortgage rights, as stipulated in the Regulation of the Minister of Finance of the Republic of Indonesia Number 27 / PMK.06 / 2016 concerning Instructions for Implementation of Auctions, the organizer is the state assets and auction service office or Kantor Pelayanan Kekayaan Negara dan Lelang (hereinafter referred to as KPKNL), which in this case is carried out by the auction office. In carrying out their duties to sell goods by auction, auction officials are given special authority by statutory regulations. ${ }^{16}$ In carrying out their duties, auction officials can be assisted by auction guides. ${ }^{17}$ The auction itself will still be carried out even though 1 (one) auction participant only attends it, and auction bidding can be made in several ways, such as: ${ }^{18}$ First, the auction bid is carried out orally (with due observance of an increase or decrease

\footnotetext{
12 Suwikromo Susan, "Hambatan Dalam Pelaksanaan Lelang Atas Jaminan Kebendaan yang Diikat Dengan Hak Tanggungan,” Lex Privatum 4, no. 1 (2016): 49-56, 49.

${ }^{13}$ Basri Efendi and Chadijah Rizki Lestari, "Penentuan Nilai Limit Oleh Bank Kreditur Berdasarkan Penaksiran Oleh Penaksir," Kanun Jurnal Ilmu Hukum 20, no. 1 (2018): 83-102, 92, https://doi.org/10.24815/kanun.v20i1.9934.

14 Yogi Gantika Gandawidura, "Perlindungan Hukum Kreditor Pemegang Hak Tanggungan Peringkat Kedua Dalam Pelaksanaan Eksekusi," Jurnal Poros Hukum Padjadjaran 1, no. 1 (2019): 73-86, 84.

15 Putu Ikaputri Ayu Paramitha, Marwanto Marwanto, and I Nyoman Darmadha, "Perlindungan Hukum Bagi Kreditur Dalam Perjanjian Kredit Dengan Jaminan Hak Tanggungan Studi di Bank BNI Cabang Gatsu Barat," Kertha Semaya 1, no. 12 (2017): 1-11, 4.

16 Article 1 Paragraph 14 of the Minister of Finance Regulation Number 27 / PMK.06 / 2016 concerning Guidelines for Auction Implementation.

17 Article 63 Paragraph (1), of the Minister of Finance Regulation Number 27 / PMK.06 / 2016 concerning Guidelines for Auction Implementation.

18 Article 64 of the Minister of Finance Regulation Number 27 / PMK.06 / 2016 concerning Guidelines for Auction Implementation.
} 
in price), written followed by oral, if the highest bid has not reached the limit value (all of which can be carried out simultaneously in one auction). Second, a written bid can be made in the presence of the auction participant or the absence of the auction participant. Third, written bidding without auction participants can be carried out by electronic email or the internet, both in an open way (open bidding) or in a secure way (closed bidding).

An offer must be made at least equal to the limit value if the auction with the limit value is announced in every auction. ${ }^{19}$ The bid submitted by the auction participant to the auction official cannot be changed or canceled by the auction participant to the auction official cannot be changed or canceled by the auction participant, except for the bid by way of a written bid without the attendance of the auction participant via closed bidding on the internet is conducted before publication the auction report. ${ }^{20}$ The auction bid held by the KPKNL is made at an inclusive auction price or an exclusive auction price. ${ }^{21}$ An auction with an inclusive auction price is conducted at the bid price, including the buyer's auction fee. ${ }^{22}$ Meanwhile, an auction with an exclusive auction price is conducted at the bid price, excluding the buyer's auction duty. ${ }^{23}$ Furthermore, in the execution auction for the payment of debts for 1 (one) debtor against several auction objects, the auction official is obliged not to continue selling the next auction object if the auction object previously offered has met the payment of the debt. ${ }^{24}$

\section{The Mechanism for Execution of Mortgage Objects and Standard Procedure for Tender at the Office of State Assets and Auction Services or Kantor Pelayanan Kekayaan Negara dan Lelang (KPKNL)}

In practice, in the field, usually, the Bank submits a request for auction of guarantee rights to KPKNL. When bank auctions off collateral, some customers accept it, and some refuse. Usually, the Bank returns to Article 200 Paragraph (11) Herzeine Inland Regelement (HIR), which states that if someone is reluctant to leave the goods being sold, the head of the district court will make a warrant so that the permanent goods are left and emptied by the person whose goods are being sold. In the execution mechanism for the object of mortgage, rights carried out by pre-auction (applying), signing of cooperation, receiving documents, checking legal aspects, reviewing and valuing assets, explaining and marketing assets, KPKNL determines the auction schedule, auction announcements by the seller, auction participants deposit money guarantee. Then, in the auction (bargaining, determination of auction winners), in determining the winner of the auction, the highest price will indeed be in the auction and immediately make payments and hand over the original goods and documents.

In connection with the determination of the auction limit value, it has also been regulated in the Regulation of the Minister of Finance of the Republic of Indonesia Number 27/PMK.06/2016 concerning Instructions for Implementation of Auctions, where the auction for the execution of mortgage rights is required in advance with the determination of the limit

\footnotetext{
19 Article 67 Paragraph (1) of the Minister of Finance Regulation Number 27 / PMK.06 / 2016 concerning Guidelines for Auction Implementation.

${ }^{20}$ Article 67 Paragraph (2) of the Minister of Finance Regulation Number 27 / PMK.06 / 2016 concerning Guidelines for Auction Implementation.

21 Article 66 Paragraph (1) of the Minister of Finance Regulation Number 27 / PMK.06 / 2016 concerning Guidelines for Auction Implementation.

22 Article 66 Paragraph (2) of the Minister of Finance Regulation Number 27 / PMK.06 / 2016 concerning Guidelines for Auction Implementation.

23 Article 66 Paragraph (3) of the Minister of Finance Regulation Number 27 / PMK.06 / 2016 concerning Guidelines for Auction Implementation.

${ }^{24}$ Article 69 of the Minister of Finance Regulation Number 27 / PMK.06 / 2016 concerning Guidelines for Auction Implementation.
} 
value in each implementation. ${ }^{25}$ The seller, in this case, is responsible for the set limit value. ${ }^{26}$ In determining the limit value, the seller refers to the appraisal. ${ }^{27}$ The appraiser himself is a party that makes an independent assessment based on his/her competence. ${ }^{28}$ In contrast, the appraiser is a party originating from the seller who carries out an assessment based on a method that can be accounted for by the seller, including curators for art objects and antiques or ancient objects. ${ }^{29}$

For the execution of the mortgage execution auction as referred to in the above processes, the limit value must be determined by the seller based on the results of the appraiser's assessment if the value is above IDR 1,000,000,000 (one billion rupiahs). Or when a bank (the creditor) will participate as a participant in the Execution Auction or Fiduciary Execution Auction, the limit value is not confidential. ${ }^{30}$ In line with this, based on the results of an interview with Casrudin, Head of the Bandar Lampung KPKNL Assessment and Service Section, that based on existing regulations, the auction limit value is still entirely determined by the seller/the Bank when it is below IDR 1,000,000,000 (one billion rupiahs). For the limit value above IDR 1,000,000,000 (one billion rupiahs), the limit value must be determined by the seller based on the assessment results from the appraiser, where the Appraisal team in determining the minimum limit value must be following the auction limit value arbitrarily. ${ }^{31}$

A similar opinion was also expressed by Marwan Djaja Putra, a bailiff at the Tanjung Karang District Court, that although the Bank determines the auction limit value based on the assessment of the Appraisal Team, it must also pay attention to the principles of the auction, especially the principle of fairness. According to him, if the collateral object has frequently been re-auctioned, but there are still no enthusiasts. The seller can carry out the auction below the taxpayer selling value or Nilai Jual Wajib Pajak (NJOP) provided that the seller/bank must notify the debtor who guarantees the object of the auction along with the opportunity for the debtor no later than 3 (three) months to sell the collateral object to be auctioned independently in the hope that the object is sold with a higher value to pay off the debt to the creditor. ${ }^{32}$ Determining the limit value, which is lower than the market price, has the potential to achieve justice. Furthermore, there is the potential for illegal acts to occur if the guaranteed object will continue to be auctioned with such a low limit value. Therefore, the determination of the limit value is attempted in such a way as to adjust to market conditions based on the concept of assessment in the Indonesian Assessment Standard or Standar Penilaian Indonesia (SPI), which is essential to put forward. ${ }^{33}$

\footnotetext{
${ }^{25}$ Article 43 Paragraph (1) of the Minister of Finance Regulation Number 27 / PMK.06 / 2016 concerning Guidelines for Auction Implementation.

${ }^{26}$ Article 43 Paragraph (2) of the Minister of Finance Regulation Number 27 / PMK.06 / 2016 concerning Guidelines for Auction Implementation.

${ }^{27}$ Article 44Paragraph (1) of the Minister of Finance Regulation Number 27 / PMK.06 / 2016 concerning Guidelines for Auction Implementation.

${ }^{28}$ Article 44 Paragraph (2) of the Minister of Finance Regulation Number 27 / PMK.06 / 2016 concerning Guidelines for Auction Implementation.

${ }^{29}$ Article 44 Paragraph (3), of the Minister of Finance Regulation Number 27 / PMK.06 / 2016 concerning Guidelines for Auction Implementation.

${ }^{30}$ Article 45 Point $\mathrm{c}$ of the Minister of Finance Regulation Number 27 / PMK.06 / 2016 concerning Guidelines for Auction Implementation.

${ }^{31}$ Results of an interview with Casrudin, Head of the Bandar Lampung KPKNL Assessment Service Section, on May 8, 2020.

${ }^{32}$ Results of an interview with Marwan Djaja Putra, a bailiff at the Tanjung Karang District Court, on May 7 , 2020

${ }^{33}$ Munir Fuady, Perbuatan Melawan Hukum: Pendekatan Kontemporer (Bandung: Citra Aditya Bakti, 2013), 13.
} 


\section{Legal Protection for Debtor Customers who are Disadvantaged in the Auction Process for Bank Credit Collateral}

Lending by banks as a financial institution must provide legal protection for both parties, namely the credit provider as the creditor and the credit recipient as a debtor. This legal protection is found through strong guarantee rights institutions that can provide legal certainty for the parties concerned. The guarantee is given to a creditor to give the debtor confidence that the debtor will fulfill his obligations arising from an engagement or agreement. If these obligations are not fulfilled, then the debtor's rights are not fulfilled so that legal remedies can be made by requesting execution of the object of the mortgage right to the District Court.

Legal protection for bank customers (debtors) as consumers of banking services must also be put forward. As also stipulated in Law Number 8 of 1999 concerning Consumer Protection, that consumer protection is all efforts aimed at ensuring legal certainty to protect consumers. ${ }^{34}$ So that legal protection for bank customers in the auction execution of mortgage rights is a necessity. Enjoying legal protection is vital to protect everyone from enjoying the rights given by law. As a representative of the state, the KPKNL can provide legal protection in the auction process. This legal protection can be realized if KPKNL carries out an auction process based on applicable legal provisions. This was confirmed by the Head of the KPKNL Assessment Service Section in Bandar Lampung, Casrudin. According to him, the protection of bank customers who become debtors is an important thing, considering that the debtor is a party directly related to the object of collateral to be auctioned. ${ }^{35}$

As stated by Akhmad Handoko, Advocate at Handoko \& Partners Law Office, the execution auction, which continues to be carried out without paying attention to the requirements as stipulated in the laws and regulations, may have the potential for Unlawful Acts as referred to in Article 1365 of the Civil Code. ${ }^{36}$ Of course, the existence of this illegal act can bring losses to various parties, especially the debtor who initially made his property collateral, then turned it into the object of the auction. Therefore, the debtor becomes the most important party whose legal interests must also be protected. According to the individual, the debtor's legal protection is to file a lawsuit against the law if an execution auction is not based on legal provisions. ${ }^{37}$ Actions against the law that occur can be in the form of First, the determination of the price (limit value) of the auction object which is so low by the creditor, even far below the market price, that it injures the principle of justice that must be considered in every auction. Second, regarding matters relating to the auction implementation process conducted by KPKNL, in some cases, it did not run according to the provisions of the prevailing laws and regulations. That way, the debtor, as the injured party, can file a lawsuit for auction cancellation to the local district court. ${ }^{38}$ The sale of objects by auction certainly does not always run smoothly and benefits both parties. However, in reality, there are still many obstacles to implementing auction sales conducted by KPKNL. In the implementation of the auction, especially the execution auction, a lawsuit's potential is very high.

The cancellation of the auction itself can be made both before and after the auction. ${ }^{39}$ As stipulated in the Regulation of the Minister of Finance of the Republic of Indonesia Number 27/PMK.06/2016 concerning Instructions for Implementation of Auctions, that in connection

\footnotetext{
${ }^{34}$ Article 1 Paragraph 1 Law Number 8 the Year 1999 regarding Consumer Protection.

${ }^{35}$ Results of interviews with Casrudin, Op.Cit.

36 Article 1365 of the Civil Code stipulates that: "Every act that violates the law and brings harm to others obliges the person who caused the loss due to his mistake to compensate for the loss".

37 Enny Martha Sasea, "UPAYA PERLAWANAN LELANG EKSEKUSI HAK TANGGUNGAN: PERSPEKTIF KREDITOR,” Amanna Gappa 28, no. 2 (2020): 87-100, 88.

${ }^{38}$ Interview with Akhmad Handoko, Advocate at the Handoko \& Partners Law Office on May 11, 2020.

39 Zakki Adhiliyati. Alvin Riza Subakti, "Perlindungan Hukum Pemegang Hak Tanggungan Yang Objeknya Dikuasai Oleh Pihak Ketiga (Studi Putusan No. 326/PDT/2015/PT.SMG),"Verstek 6, no. 2 (2018): 13-23, 16.
} 
with the auction being held, it can be canceled at the request of the seller or based on a ruling or decision from a judicial institution. ${ }^{40}$ The regulation regarding the cancellation of an auction that can be carried out based on the stipulation or decision of a judicial institution can be used as a legal reference in guaranteeing legal protection for bank customers to implement the auction execution of mortgage rights. ${ }^{41}$ Cancellation of the auction before the implementation of the auction may originate from a Court Decision. It is published in writing. The time for submission of the Auction Official decision is no longer than before the auction is held. ${ }^{42}$

If the auction decision states that the auction is canceled and invalid, the auction object will return to its original state to return to the debtor as the owner of the object. That way, the original guarantee binding, and debt will remain in their original condition. Meanwhile, legal protection by canceling the auction after the auction is carried out is due to force majeure or force majeure or technical problems that cannot be resolved during the auction without the presence of auction participants. ${ }^{43}$ The problem that the cancellation of the auction may cause after the auction is completed is that there are other parties whose legal interests are harmed in connection with the occurrence of auction cancellations.

\section{Conclusions}

Based on the description above, conclusions can be drawn in the form of First, the auction for the execution of mortgage rights can be an alternative settlement of bad debts caused by the customer (the debtor) in default. The Bank as the creditor has the right to collect receivables from the sale of the object of the mortgage, which is guaranteed by an auction mechanism under the provisions of Law Number 4 of 1996 concerning Land and Other Objects Related to Land and Regulation of the Minister of Finance of the Republic of Indonesia Number 27 PMK.06 / 2016 concerning Guidelines for Bid Implementation. Second, based on the provisions of Article 43 and Article 44 of the Regulation of the Minister of Finance of the Republic of Indonesia Number 27/PMK.06/2016 concerning Instructions for Implementation of Auctions, determining the limit value in auction implementation is an important matter that must be adhered to and carried out properly by the Seller or the Security Guarantee Holder. In this case, the limit value determined by the Bank as the seller must be based on the results of the appraisal. If the determination of the auction limit value is lower than the market price or liquidation value, it can be used as a reason for the cancellation of the auction. Third, as a guarantee of legal protection for customers, if there is a loss due to the implementation of an auction that is not based on the prevailing laws and regulations, the auction can be canceled through a judicial decision or decision as referred to in Article 27 of the Regulation of the Minister of Finance of the Republic of Indonesia Number 27 /PMK.06/2016 concerning the Tender Implementation Guidelines. That way, the customer can file a legal action in the form of a lawsuit against the auction with a lawsuit against the law referred to in Article 1365 of the Civil Code at the local district court.

\footnotetext{
${ }^{40}$ Article 27 of the Minister of Finance Regulation Number 27 / PMK.06 / 2016 concerning Guidelines for Auction Implementation.

${ }^{41}$ Jumiati Jumiati, "Pelaksanaan Lelang Hak Tanggungan Pada Bank BNI Syariah Kantor Cabang Medan," Media Komunikasi dan Informasi Hukum Dan Masyarakat 18, no. 1 (2018): 22-29, 24.

${ }^{42}$ Article 28 Paragraph (1) of the Minister of Finance Regulation Number 27 / PMK.06 / 2016 concerning Guidelines for Auction Implementation.

${ }^{43}$ Article 31 of the Minister of Finance Regulation Number 27 / PMK.06 / 2016 concerning Guidelines for Auction Implementation.
} 


\section{A. Journal}

\section{REFERENCES}

Adhiliyati, Zakki., Subakti, Alvin Riza. "Perlindungan Hukum Pemegang Hak Tanggungan Yang Objeknya Dikuasai Oleh Pihak Ketiga (Studi Putusan No. 326/PDT/2015/PT.SMG)," Verstek 6, no. 2, 2018: 13-23.

Alfara, M. Ichsan. "Perlindungan Hukum Bagi Pemenang Lelang Eksekusi Hak Tanggungan Dalam Hal Objek Lelang Yang Tidak Sesuai Dengan Pengumuman Lelang (Studi Kasus Putusan Pengadilan Negeri Manado Nomor 123/PDT.G/2018/PN.MND)," Notary 2, no. 1, 2020: 622-645.

Efendi, Basri., Lestari, Chadijah Rizki. "Penentuan Nilai Limit Oleh Bank Kreditur Berdasarkan Penaksiran Oleh Penaksir," Kanun Jurnal Ilmu Hukum 20, no. 1, 2018: 83102, DOI: 10.24815/kanun.v20i1.9934.

Gandawidura, Yogi Gantika. "Perlindungan Hukum Kreditor Pemegang Hak Tanggungan Peringkat Kedua Dalam Pelaksanaan Eksekusi," Jurnal Poros Hukum Padjadjaran 1, no. 1, 2019: 73-86.

Jufri, Supriadi., Borahima, Anwar., Said, Nurfaidah. "Pelaksanaan Lelang Eksekusi Hak Tanggungan Melalui Balai Lelang." Jurnal Ilmiah Dunia Hukum 4, no. 2, 2020: 95-107, DOI: $10.35973 /$ jidh.v4i2.1379.

Jumiati. "Pelaksanaan Lelang Hak Tanggungan Pada Bank BNI Syariah Kantor Cabang Medan," Media Komunikasi dan Informasi Hukum dan Masyarakat 18, no. 1, 2018: 22 29.

Laily, Nur., et al., "Analisis Perlindungan Hukum Terhadap Peserta Lelang Dalam Pelaksanaan Eksekusi Hak Tanggungan Oleh Pihak Bank," Reformasi Hukum 24, no. 2, 2020: 209-228, DOI: 10.46257/jrh.v24i2.140.

Paramitha, Putu Ikaputri Ayu., Marwanto., Darmadha, I Nyoman. "Perlindungan Hukum Bagi Kreditur Dalam Perjanjian Kredit Dengan Jaminan Hak Tanggungan Studi di Bank BNI Cabang Gatsu Barat," Kertha Semaya 1, no. 12, 2017: 1-11.

Sasea, Enny Martha. "Upaya Perlawanan Lelang Eksekusi Hak Tanggungan: Perspektif Kreditor," Amanna Gappa 28, no. 2, 2020: 87-100.

Sulastri, Lusia. "Konstruksi Perlindungan Hukum Debitur Dalam Penyelesaian Kredit Bermasalah Dengan Pelaksanaan Lelang Jaminan Hak Tanggungan." Jurnal Pembaharuan Hukum 2, no. 1, 2016: 86-101, DOI: 10.26532/jph.v2i1.1418

Suryono, Arief., Pranamawati, Yelina Rachma. "Perlindungan Hukum Pembeli Lelang Terhadap Pelaksanaan Eksekusi Hak Tanggungan Yang Risalah Lelangnya Dinyatakan Tidak Sah dan Tidak Mempunyai Kekuatan Hukum Mengikat Oleh Pengadilan," Repertorium 5, no. 1, 2018: 220-235.

Susan, Suwikromo. "Hambatan Dalam Pelaksanaan Lelang Atas Jaminan Kebendaan Yang Diikat Dengan Hak Tanggungan," Lex Privatum 4, no. 1, 2016: 49-56.

Walidani, Lutfi., Adjie, Habib. "Perlindungan Hukum Kreditur Terhadap Pelaksanaan Eksekusi Hak Tanggungan (Analisis Putusan Mahkamah Agung Republik Indonesia Nomor 2859K/PDT/2011)," Hukum dan Masyarakat Madani 8, no. 2, 2018: 117-130, DOI: $10.26623 /$ humani.v8i2.1377.

Widyanti, Akira. "Pelaksanaan Lelang Eksekusi Oleh Kreditur Terhadap Jaminan Sebagai Sarana Pelunasan Hutang Debitur Berdasarkan Pasal 6 Ayat (1) Undang-Undang Nomor 4 Tahun 1996 Tentang Hak Tanggungan," Rechtsregel: Jurnal Ilmu Hukum 3, no. 1, 2020: 132-146, DOI: 10.32493/RJIH.V3I1.6625.

\section{B. Book}

Effendi, H.A. Masyhur. Hak Asasi Manusia dalam Hukum Nasional dan Internasional. Jakarta: Penerbit Ghalia Indonesia, 1994. 
Gandapradja, Permadi. Dasar dan Prinsip Pengawasan Bank. Jakarta: Gramedia Pustaka Utama, 2004.

HS, Salim., Erlies Septiana Nurbani. Penerapan Teori Hukum pada Penelitian Tesis dan Disertasi. Jakarta: Raja Grafindo Persada, 2013.

Rahman, Hasanuddin. Aspek-Aspek Hukum Pemberian Kredit Perbankan di Indonesia. Bandung: Citra Aditya Bakti, .1995.

Rivai, Veithzal. Islamic Finacial Management. Jakarta: Raja Grafindo Persada, 2008.

Usman, Rachmadi. Aspek-Aspek Hukum Perbankan di Indonesia. Jakarta: Gramedia Pustaka Utama, 2003.

\section{Regulations}

Law Number 4 of 1996 concerning Mortgage Rights for Land and Other Objects Related to Land.

Law Number 8 of 1999 concerning Consumer Protection.

Regulation of the Minister of Finance of the Republic of Indonesia Number 27/PMK.06/2016 concerning Guidelines for Auction Implementation.

\section{Internet}

https://www.djkn.kemenkeu.go.id/kpknl-batam/baca-artikel/12599/Mendorong-EfektivitasLelang- Eksekusi-Hak-Tanggungan.html, Accessed on May 28, 2020.

\section{E. Supporting Source}

An interview with Marwan Djaja Putra, a bailiff at the Tanjung Karang District Court, was on May 7, 2020.

An interview with Shinta Dewi, Head of Bank Mayora's Credit Operations Division, on May $02,2020$.

Interview with Akhmad Handoko, Advocate at the Handoko \& Partners Law Office, on May $11,2020$.

Results of an interview with Casrudin, Head of the Bandar Lampung KPKNL Assessment Service Section, on May 8, 2020. 
